\title{
The Impact of Human Resource Practices on Actual and Perceived Organizational Performance in a Middle-Eastern Emerging Market
}

\author{
Tamer K Darwish, Satwinder Singh, and Geoffrey Wood
}

\begin{abstract}
This is a study of the impact of the specific sets of HRM practice on organisational performance within an emerging market setting. It seeks to explore which HR practices are most closely associated with better organisational performance within the financial services industry in Jordan based on a survey of managers and objective companies data, and the broader implications thereof. It also sheds new light on the relative reliability of management perceptions of organisational performance when compared with more objective measures. It was found that the only HR practice seen to consistently impact both objective and subjective performance was the relative emphasis placed on training: the latter is an ambiguous measure, and, inter alia, can reflect a long-term commitment by a firm to its people, or considerable attention being dedicated to the induction and orientation of new staff in response to high staff turnover rates. Although belied by objective firm performance data, many respondents believed that the extensive usage of extrinsic incentives (pay and promotion) was bound to translate into superior results. This highlights both the limitations of relying on managerial reported performance data in exploring the consequences of specific HR practices, and the limited transferability of perceived best practice models within emerging market settings.
\end{abstract}

Keywords: HR practices, perceived and actual performance, emerging markets, exploratory and confirmatory factor analysis, convergent and discriminant validity, hierarchical regressions.

\section{Introduction}

This is a study of the impact of specific sets of HRM practice on organisational performance (OP) within an emerging market setting. Although much of the HRM literature holds that effective people management represents a durable source of competitive advantage (Pfeffer, 1994, 1998; Schuler \& Jackson, 1999; Khandekar \& Sharma, 2005; Darwish and Singh, 2013), somewhat less clear is which of the specific HR practices are most likely to enhance performance (Becker \& Gerhart, 1996; Dyer \& Reeves, 1995; Wright \& Gardner, 2003; Paauwe, 2009; Guest, 1997, 2011; Singh et al., 2012), and how performance may best be measured (c.f. Paauwe \& Boselie, 2005; Darwish \& Singh, 2013). Moreover, it has been 
argued that it is an interrelated system of HR practices that enhances performance, with one practice encountered on its own not having the same result than when encountered in combination with others (Ichniowski \& Shaw, 1999). Sets of practices may add value to a firm in a range of different ways, such as through promoting greater cost-cutting or unleashing new synergies (Barney, 1991). As a large body of institutional literature reminds us, the viability of specific practices is closely related to setting, including sector (Amable, 2003).

There is a broad body existent literature that explores the impact of different sets of HR practices on organisational performance, although individual studies have tended to focus on a limited range of practices and/or to concentrate on mature market settings (Becker \& Gerhart, 1996; Dyer \& Reeves, 1995; Wright \& Gardner, 2003; Paauwe, 2009; Guest, 1997, 2011; Singh et al., 2012). In contrast, this study looks at a relatively broad range of practices, within a key sector in an emerging market setting. Webster \& Wood (2005) argue that, within emerging markets, firms may rely on people management practices that are far removed from the conceptualisations of HRM encountered in the advanced societies. Hence, the deployment of 'modern' forms of HRM may have little or no effect on performance, given specific societal and economic realities.

This article has three main objectives: firstly, to explore the direct impact of specific set of HRM practices on organisational performance within the financial services industry in Jordan; secondly, to shed new light on the relationship between subjective and objective measures of organisational performance; and thirdly, whilst the potential impacts of HRM practices on performance is still a hugely debatable issue between the contingency and universalistic researchers, the present article, based on its findings in a non-Western context, also aims to explore whether or not it is true that Western-derived models of best practice have little relevance on an emerging market. As is the case with many other countries in 
Jordan, the financial sector occupies a prominent position within the services sector; this sector is the largest and most well-developed services sector in the country, and is witnessing a great deal of deregulation, which is notably attracting private investment from within the country and overseas. This sector had been largely insulated from the recent financial crisis because of its as yet limited exposure to overseas capital markets; it is also the largest area of the Jordanian economy, accountable for a greater percentage of total GDP than any other sector (Bahous, 2006; World Fact Book, 2009).

In addition, this sector was also selected owing to its increasing prominence in many national settings, and because it is often seen as a pioneering innovations that impact on other firms across an economy (Froud et al., 2006; Erturk et al, 2008). More specifically, within many national contexts, financial sector players have sought to actively promote peoplemanagement practices centring on a narrow conceptualisation of agency theory, which suggests that managers - and, by extension, employees - are rational actors that will depart from the agenda of maximising shareholder value, unless closely reigned in, with continued tenure and reward contingent on performance (Jensen, 2000). Hence, it could be argued that firms within the financial services sector are particularly likely to promote specific sets of HR practices (both externally, and seek to emulate them internally), and that these may directly impact performance (see Froud et al., 2006; Erturk et al., 2008). Jordan is a relatively developed and stable (and secular) Middle Eastern country with a significant industrial and commercial base. If specific sets of HR practice derived in the West are unable to generate significant performance improvements in such a setting, arguably, this would cast doubt on the broader relevance of such practices across much of the developing world. Again, firms operating in the wider Middle East region could learn useful lessons from what works in the Jordanian context, and what does not. 
This paper is structured as follows: firstly, we highlight key strands of the existing HR literature that seeks to link together specific sets of HR practices with performance; secondly, we compare and contrast subjective and objective ways of measuring organisational performance; thirdly, we introduce the context of the present study; fourthly, we describe our methods and fifthly, our results; and finally, we move on to our conclusions, discuss their broad relevance, and draw out the implications for practice. In short, what we aim to do is identify which HR practices correspond with superior organisational performance in an emerging market setting, and whether or not these correspond with any identifiable Western paradigm of people management.

\section{Theoretical Perspectives on HRM-performance Link}

During the course of many decades, the field of HRM has attracted much attention across various disciplines owing to its contribution to and impacts on the bottom-line issues within organisations. The debate centres on an integrated management approach of how the entire set of HRM practices may eventually contribute to the competitive advantage of the organisation (Arthur, 1994; Huselid, 1995; Delery \& Doty, 1996; Singh et al., 2012; Darwish \& Singh, 2012). Such a transition reflects the importance of human resources in terms of gaining competitive advantage and achieving organisational performance (Singh et al., 2012). However, thus far, empirical research evidence has only partially verified the impact of HRM practices on performance (Pfeffer, 1994, 1998; Guest, 2011). Several researchers (for example, Paauwe \& Boselie, 2005; Wright et al., 2005; Paauwe, 2009; Guest, 2011) demonstrate several inconsistencies, commenting that the nature of the HRM-performance link is ambiguous, and this area of research in particular needs more empirical work, and from different contexts.

HRM-performance: The Nature of the Link 
Since the notion of the HRM-performance link has emerged, two research streams have been developed in mind of examining the relationship between specific sets of HRM practices and performance. The first stream is based on the direct relationship between individual HR practices and/or bundles or systems of practices and organisational performance (Schuler \& Jackson, 1999; Chand \& Katou, 2007). The second research stream is based on the indirect relationship between individual HR practices and/or bundles of practices and performance (Wright \& Gardner, 2003). With regard to the first path, studies on the HRM-performance link suggest specific HR practices that can lead to competitive advantage and, as a result, will provide the basis of superior organisational performance (Pfeffer, 1994; MacDuffie, 1995; Huselid, 1995; Delaney \& Huselid, 1996; Guest, 1997). These specific practices-geared toward helping firms achieve better results - have been assigned different terms by different researchers, such as 'best practices' (Pfeffer, 1994), 'high performance work system (HPWS)' (Huselid, 1995; Way, 2002), 'high-involvement practices' (Wood \& De Menezes, 2008), and 'high commitment practices' (Arthur, 1994). Any identified optimal combination of HR practices essentially encompasses an element of selectivity (Guest, 1997; Brewster et al., 2008). However, regardless of the progress achieved by researchers thus far in terms of measuring HR practices, there is no consensus amongst researchers on what optimal practices could be or the number of practices that could enhance organisational performance (Dyer \& Reeves, 1995; Becker \& Gerhart, 1996; Wright \& Gardner, 2003; Brewster et al., 2008; Guest, 2011).

Within a second, alternative research stream, researchers have criticised the way in which HRM impacts on organisational performance, arguing that whether individual or in a bundle, HR practices do not directly affect firm performance (Katou \& Budhwar, 2007). Further, HR practices could directly impact some meditating variables (for example, employee turnover, 
productivity) which, in turn, affect firm performance; this is what can be termed as the 'black box' in HRM-performance research. However, as there is no established method available to researchers to determine which HR practices could (indirectly) impact on organisational performance, little attention has been paid to exploring this aspect of research any further (Wright \& Gardner, 2003; Wright et al., 2003). Hence, the present study aims to directly investigate the impacts of specific set of HRM practices on organisational performance.

\section{The Concept of Organisational Performance}

OP is one of the most broadly and extensively used dependent variables in organisational studies today, and yet, at the same time, this construct remains one of the most imprecise and loosely defined (Rogers \& Wright, 1998). For many years, researchers have been struggling to establish a clear and precise meaning for OP, which is not only limited to the field of HRM but which is also applicable to many other fields (ibid.). Although the positive links between different HR practices and OP have been explored, in actual practice, the measurement process is a complex task. As a result, it is not surprising that, despite several attempts to do so, a fool-proof method still remains elusive (see Guest, 1997; Rogers \& Wright, 1998; Paauwe \& Boselie, 2005). Scott (1977, p. 63), in his review of the measures of organisational effectiveness, concludes that, 'after reviewing a good deal of the literature on organisational effectiveness and its determinants, I have reached the conclusion that this topic is one about which we know less and less'. Conceptually, OP has been defined as the comparison of the value produced by a company with the value owners expected to receive from the company (Alchian \& Demsetz, 1972). Venkatraman \& Ramanujam (1986, p. 803) indicate that a narrow definition of performance centres on the use of simple outcome-based financial indicators that are assumed to reflect the fulfilment of the economic goals of the firm. Performance can also be defined in terms of stakeholder well-being (Dyer \& Reeves, 1995). Furthermore, the term may also be described in terms of financial indicators (profits, sales, 
return on assets) or capital market outcomes (market share, Tobin's $q$, stock price, and growth). Importantly, in the strategy literature, the focal point of attention on this construct has been almost completely on financial measures of performance (Rowe et al., 1995).

In contrast, the majority of the studies cantered on the HRM-performance link use subjective financial measures when striving to assess $\mathrm{OP}^{1}$. It would be more appropriate and rewarding to use multi-dimensional measures for OP as these measures could include various objective variables to reduce the probability of common method variance (Wall \& Wood, 2005), and to thereby avoid misleading normative and descriptive theory-building (Lumpkin \& Dess, 1996). Wall \& Wood (2005) argue that an important limitation in HRM-performance research is that both variables (HRM and performance) are measured using the same source. In actual fact, objective measures reflect the economic rationality, which emphases outcomes, such as productivity and other financial indicators. Subjective measures, in contrast, reflect the normative rationality, which notably emphasise more behavioural and societal aspects of OP.

Hence, much of the HR literature favours the usage of subjective measures of organisational performance (Razouk, 2011). It is true that objective measures may introduce limitations of their own through the increased risk of measurement errors and the effects of national variations in accounting standards; however, it has been argued that such measures remain more robust than subjective ones given the extent to which managers may seek to overstate performance, inter alia, owing to a reluctance to draw attention to their own shortcomings (see, for example, Dess \& Robinson, 1984; Geringer \& Hebert, 1991; Powell, 1992; Fey et al., 2000; Bjorkman \& Budhwar, 2007; Razouk, 2011). A body of existing research suggests that the results obtained by subjective and objective measures tend to be broadly comparable

\footnotetext{
${ }^{1}$ Delaney \& Huselid, 1996; Wright et al., 1999; Fey et al., 2000; Richard \& Johnson, 2001; Chang \& Huang, 2005; Green et al., 2006; Andersen, 2007; Chand \& Katou, 2007; Bjorkman \& Budhwar, 2007; Macky \& Boxall, 2007; Beltran-Martin et al., 2008; Joseph \& Dai, 2009; Katou \& Budhwar, 2010; Lee et al., 2010; Moideenkutty et al., 2011; Razouk, 2011.
} 
(Dess \& Robinson, 1984; Tzafrir, 2005). For instance, Dess \& Robinson (1984) suggest that self-reported OP measures are acceptable and are as equally reliable as objective measures; they correlate the subjective measures of performance with self-reported objective measures (collected through surveys as opposed to from the actual financial statements of the companies). In one of the earliest studies, Powell (1992) highlights various positive connections between the subjective and objective measures of OP (sales growth and profitability) on a subset of 52 firms from his studied sample in the US. In summary, there is an extensive body of HR literature based on subjective measures of performance, whilst within the wider strategy literature, objective measures have tended to be favoured. In contrast to the very extensive bodies of literature in each camp, there is a far more limited range of studies comparing these two measures, with none (of which we are aware) conducted in an emerging market setting. Yet, given the possibility that locally dominant managerial ideologies may mould perceptions, it can be argued that it is vital to include such a comparison, especially in an emerging market setting where there is relatively little existing research.

\section{HRM-Performance: Does the Context Matter?}

As noted above, extant research on direct HRM-performance links suggest specific HR practices that can lead to competitive advantage and which can, as a result, enhance organisational performance (Pfeffer, 1994; MacDuffie, 1995; Huselid, 1995; Delaney \& Huselid, 1996; Guest, 1997). On the one hand, any combination of HR practices essentially encompasses an element of selectivity (Guest, 1997; Brewster et al., 2008). Hence, there is little consensus amongst researchers on the nature and optimal configuration of practices that could enhance organisational performance (Dyer \& Reeves, 1995; Becker \& Gerhart, 1996; Wright \& Gardner, 2003; Brewster et al., 2008; Guest, 2011). On the other hand, a common theme across much of the literature is that HR practices tend to form coherent bundles, 
which, in objective terms, lie towards one or the other end of a 'hard'/'soft' spectrum (Guest, 2011; Brewster et al., 2008). Although each brings with it particular benefits and costs, it has been argued that, within advanced societies, firms will tend to adopt people management strategies towards one or other of these poles (Lincoln \& Kalleberg, 1990; Dore, 2000; Hall \& Soskice, 2001; Guest, 2011). 'Softer' stakeholder-orientated notions of best practice suggest that optimal results will be engendered through careful recruitment coupled with relatively secure tenure and a strong emphasis on internal career development and investment in people, and fairness and transparency in incentives and rewards (Pfeffer, 1998; Huczynski \& Buchanan, 2007). In contrast, 'harder', more shareholder-value-orientated approaches rest on the assumption that individuals need to be firmly orientated to the bottom line through linking rewards and career progress to performance, and, indeed, regular appraisals (Hollingworth, 2009).

Contingency-orientated approaches hold that specific sets of practice will continue to work better in some social settings rather than others (Brewster, 2007; Storey, 2007). Such assumptions underpin the undeniably diverse theoretical literature on comparative capitalism (see Dore, 2000; Hall \& Soskice, 2001; Whitley 1999). The latter suggests that institutions play a vital role in mediating social relations both within and between firms, engendering and maintaining specific patterns of behaviour (ibid.). This will result in combinations of rules, relations and practices within particular settings being complementary; in other words, likely to generate superior results owing to specific institutional supports (Hall \& Soskice 2001).

A large component of the early literature on comparative capitalism was dichotomous, dividing the developed world into liberal (LMEs) and coordinated market economies (CMEs); the former the Anglo-Saxon economies, the latter north-western continental Europe and Japan (Hall \& Soskice, 2001; Dore, 2000; Lincoln \& Kalleberg, 1990). Each archetype 
was associated with relative competitive advantages, and linked to specific sets of HR and other firm-level practices (ibid.). The latter would, inter alia, reflect variations in relative shareholder and countervailing employee and other stakeholder power, employment legislation, and skills and training infrastructures. In practical terms, it is held that harder, more instrumental HR approaches are more closely aligned with the broader systemic order, and represent the dominant paradigm within LME settings, and likewise, softer ones in CME ones (Gooderham et al., 1999, 2006; Dore, 2000).

Whilst the early literature on comparative capitalism assumes that most other economies drift to one or another of these two mature models on account of their known complementarities (Hall \& Soskice, 2001), critics have argued that other types of national economy would be likely to retain their distinct characteristics (Hancke et al., 2007). In practical terms, this raises the question as to whether, in a developing world setting, the types of HR practices capable of generating superior results would be similar to the dominant paradigm of one of the two mature models, or would be likely to have distinct features. On the one hand, it could be argued that, particularly within an industry such as financial services, there are strong pressures on firms to adopt policies and practices historically associated with the LME model. On the other hand, existing literature on people management in the developing world suggests that HR practices will retain distinct features often associated with higher levels of communitarianism, and with authoritarian-paternalistic management approaches being mitigated by informal ties and flexibilities (Webster \& Wood, 2005; Jackson et al., 2008). This would suggest that the sets of HR practices encountered within the Jordanian financial services industry that generate optimal organisational performance will not necessarily correspond to recognisable bundles of practices (whether instrumentalist/hard or cooperative/soft) that are seen as generating superior results for Western firms operating in specific mature markets (see Webster \& Wood, 2005). There is very limited research on 
HRM in Jordan, although a strand of existing work highlights the importance of local values and conventions (centring on strong notions of clan and community) in underpinning HR practice (Aladwan et al., 2011), as well as structural economic realities, namely high unemployment (Altarawmneh \& Al-Kilani, 2010). Al-Hasan \& James (2003) state that the Jordanian institutional and cultural setting appears to exert a relatively weak pull on MNC subsidiary practices, perhaps indicating a relatively high degree of fluidity; this may also reflect the extent to which strong informal networks may not necessarily provide a coherent substitute for more formal societal institutions in providing a stable foundation for particular organisational practices as a basis for growth (c.f. Hancke et al., 2007).

Recent work has highlighted the extent to which institutions and associated wider societal relations may impact on the viability of specific sets of work and employment practices - not only on national lines, but also on sectoral ones (Lane \& Wood, 2009). In this regard, a commonly drawn distinction is between manufacturing and services-sector work, and, more recently, in the latter, the specific characteristics of the financial services industry, which, as noted above, has been often seen as a pioneer of innovation (Froud et al., 2006; Erturk et al., 2008). There is a very diverse body of literature that suggests that, whether for desirable (Jensen, 2000) or undesirable (Streeck, 2009) reasons, practices associated with the LME model will inevitably overwhelm all others, and that such innovations will flow from the financial services sector (Erturk et al., 2008).

In summary, comparative institutional approaches suggest that, within specific contexts, a particular dominant mode of HR practices will be supported by systemic features and complementarities, and hence confer firms with competitive advantages (Hall \& Soskice, 2001). LMEs are associated with hard instrumental practices, and CMEs with softer, cooperative ones (Gooderham et al., 1999; Dore, 2000). On the one hand, it could be argued 
that, when removed from its respective institutional supports, each paradigm would be unlikely to work as well (see Dore, 2000; Hall \& Soskice, 2001). In short, in an emerging market setting, it is unlikely that either Western style hard or soft HRM will generate the same superior results as within mature contexts; rather, strongly performing firms will be likely to be deploying distinct HR models, probably with more pronounced paternalist and/or communitarian features (Webster \& Wood, 2005). On the other hand, it could be argued that, particularly within innovative sectors, such as financial services, leading firms are likely to be pioneering harder practices associated with the LME model (see Dore, 2000; Erturk et al., 2008). The potential for pioneering innovation may be rather pronounced in developing world settings where there is greater contextual fluidity (see Suresgchandar et al., 2002).

\section{The Research Context}

Jordan occupies a strategic location within the Middle East. In recent years, Jordan has opened up its markets to world trade and investment, and is fast becoming a credible player in global commerce. Jordan's stock exchange has become one of the fastest growing open avenues for foreign investors. This growing international integration is exposing the country to both regional and international competition and risks (Al-Shammari \& Hussein, 2008), which has subsequently coaxed companies into becoming increasingly competitive; however, given its limited natural resources, the onus is falling on the services sector, which contributes over $75 \%$ to the country's national income. Importantly, the financial sector is the largest and best developed services sector in the country, and is witnessing a great deal of deregulation, which is attracting private investment from within the country and overseas; this sector had been largely insulated from the recent financial crisis because of its somewhat limited exposure to overseas capital markets (Bahous, 2006; World Fact Book, 2009; Singh et al., 2012). Nevertheless, this is changing fast, as became evident during the course of the 
research for this paper, when the authors spoke to a large number of HR directors in charge of financial issues.

Existing research on HRM in Jordan has highlighted the extent to which the inhospitable external labour market means that employees are likely to seek to hold on to existing jobs, even if terms and conditions of service are sub-optimal. This could eliminate excessive churn, and may mean that workers are more likely to tolerate sub-optimal HR practices but at the cost that workers are primarily negatively committed to the firm, with implications for productivity and performance (Altarawneh \& Al-Kilani, 2010).

\section{Central Propositions}

In view of the above, the study has two broad central propositions. The first is that the sets of HR practices associated with optimal organisational performance (whether according to objective or subjective measures) in the Jordanian setting will not necessarily correspond with either the hard/instrumentalist or soft/cooperative Western models. Rather, the most effective sets of practices will be in line with national and sectoral complementarities, and specific historical and cultural traditions. As an alternative to this, it could be argued that practices encountered will broadly correspond with one or another of these models. Given that the shareholder value paradigm is likely to be particularly advanced within the financial services industry (Froud et al., 2006; Erturk et al., 2008), and the industry's role in disseminating practices associated with the liberal market/shareholder dominant model, it is possible that the most effective practices encountered will be of the more instrumentalist variety.

The second is that subjective measures of performance are likely to correspond broadly with more objective ones (c.f. Dess \& Robinson, 1984; Tzafrir, 2005). In other words, both 
represent equally valid ways of measuring organisational performance, and the sets of $\mathrm{HR}$ practices associated with each are likely to be interchangeable.

\section{Methodology}

\section{Data and Sample}

The target population of this study is the financial sector of Jordan. A count of all the firms operating in the financial sector revealed a population of 104 firms in banking, insurance, real estate, brokerage and other financial services. These firms are all listed on Amman Stock Exchange (ASE). The unit of analysis in the present work is the organisation, with the targeted respondents including HR directors in the targeted companies, following almost all the work that has been conducted in the HRM-performance link. It was decided that all the firms in the population be approached for the purpose of data collection. We required two types of data for the study: the first set comprising primary data relating to the HRM operations of these firms; the second relating to their financial operations. A detailed questionnaire was drafted to gather the primary data. All 104 firms were contacted in person, of which 99 agreed to participate in the survey. Questionnaires were delivered by hand and collected in person. Cross-checks revealed data to be consistent and reliable. The matching financial data from profit and loss accounts and the balance sheets of the 99 firms were collected from the financial statements from ASE. Fortunately, government policies and regulations require all the listed companies to report the financial data in a consistent manner, which makes the inter-firm comparisons meaningful and unbiased.

\section{Methods}

In order to test the prepositions stated, the following approaches were adopted. First, exploratory factor analysis was conducted for all HRM practices with the aim of summarising 
and grouping together data that was correlated. Additionally, in order to test the validity of the variables under consideration, confirmatory factor analysis was carried out. The descriptive analysis of data (Table 2 and Table 3) includes mean, standard deviation, skewness and kurtosis, and zero-order correlations. Hierarchical regression analysis is adopted for modelling the data. Prior to conducting the regression analysis, data was screened and tested for multivariate assumptions. Outliers test was conducted; the results revealed no extreme cases. Furthermore, the results of normality test revealed that the skewness and kurtosis values lie within the acceptable ranges, except for firm size and firm age, which were then transformed into logs. The relationships between variables were homoscedastic as they all met the normality assumption (Tabachnick \& Fidell, 2007). Tests also revealed the absence of multicollinearity between the variables.

\section{Construction of HR Practices}

Scales were built in order to measure HR practices and perceived financial performance for the first half of the study. Any mixture of HR practices essentially encompasses an element of selectivity (Guest, 1997; Brewster et al., 2008). The measures of HR practices were developed based on existing HRM literature. Our focus on HR practices has been developed based on the works of Delery \& Doty (1996), Casson et al., (1996, 1997, 1998) and Pfeffer (1998), with the former having identified a set of HR practices of strategic import. In turn, their work is based on the theoretical and empirical work of Miles \& Snow (1984), Osterman (1987), Kerr \& Slocum (1987), and Sonnenfeld \& Peiperl (1988). Hence, in this study, the HR practices scale covers five key areas of HRM: recruitment and selection; training; internal career opportunities; performance appraisals; and incentives and rewards. Recruitment and selection included questions on formal and informal qualifications and personal characteristics that companies considered in appointing an employee to a middle-grade 
general management job. The training question related to the most applicable methods (of training). Internal career opportunities referred to as the main criteria of individual or group performance used in assessing cases for promotion. All questions were measured on a Likert scale ranging from 1 'not applicable' to 5 'always applicable'. Performance appraisal question inquired into how frequently appraisals were conducted and how fast feedback was dispensed. Finally, in the incentives and rewards section, three questions were posed, the first of which queried how the salary differentials were explained to employees (in other words, transparency in pay); the second asked questions on policies adopted to retain key staff (in other words, sensitivity to external labour market pressures); the third queried the benefits for an employee for working for the company (in other words, does the firm pay the minimum rate according to external labour market conditions or does it seek to provide superior pay to promote organisational commitment?). Such questions and their items were measured on a Likert scale ranging from 1 'not important' to 5 'very important'. All items measuring HR practices are shown in Table 1.

\section{Exploratory Factor Analysis of HR Practices}

Factor analysis poses the question concerning how a large set of variables can be substituted by a smaller one that best reflects the large set (Wood et al., 2009). We performed principal component factor analysis with Varimax rotation for all the HR practices as shown in Table 1. As proposed by Hair et al. (2010) in a sample of 100 respondents, factor loadings of .55 and above are considered significant. As a result, some items were deleted as they lacked variations and caused interpretability problems at the conceptual level. The outcomes generated only one factor for each variable except incentives and rewards. Two factors were generated for this variable; they explained $41.65 \%$ of the total variance. The first factor is entirely associated with extrinsic incentives and rewards, such as pay increase and valuable fringe benefits. The second factor, in contrast, is entirely associated with intrinsic incentives 
and rewards, such as a friendly and supportive work environment. This is consistent with the theoretical structure proposed by DeCenzo \& Robbins (2005). The results confirm a robust and comprehensive structure of incentives and rewards. Therefore, the first factor was labelled as 'extrinsic incentives and rewards', whilst the second factor was labelled as 'intrinsic incentives and rewards'.

\section{Convergent and Discriminant Validity of HR Practices}

We conducted confirmatory factor analysis, which provided three main indicators to assess the convergent validity (Table 1) in the form of factor loadings, average variance extracted (AVE), and reliability of the construct (Hair et al., 2010). The results show that the factor loadings of each construct indicator are significant, ranging from 0.56 to 0.90 , demonstrating a strong association between constructs and their factors. Further, the results indicate that AVE values were higher than the threshold value of 0.50 , demonstrating adequate convergence of the constructs. Finally, the results of the Cronbach's alpha test indicate that the scales satisfy the reliability criterion, with values ranging from .61 to .95 . Two of our HRM scales had low reliabilities (training $\alpha .63$; and performance appraisals $\alpha .61$ ). Low reliability values of HRM scales have also encountered several researchers in HRMperformance research (see, for example, Huselid, 1995) where he reported Cronbach's alpha estimates of.66 and .67 for his HRM scales. This could be explained by multiple reasons. The first and most logical one is that these two scales had less measuring items comparing to the other scales which actually would cause low reliability estimates (see DeShon, 1998; Gerhart et al., 2000). In addition, we gathered our data from single-rater which could also have an impact on reliability estimates. Gerhart et al., (2000) found single-rater reliabilities to be frighteningly low. Such results were also supported by Wright et al., (2001). Wright et al., (2003) claim that the reliability of single-raters may be close to zero. Gerhart et al., (2000) 
and Huselid and Becker, (1996) argued that coefficient alpha is an inadequate estimate of reliability as it ignores measurement error due to other sources such as raters. Reliability estimates would be lower if there is measurement error due to raters, meaning that the correction factors would become larger (for more details on this issue, see Gerhart, 2000). Moreover, low reliability estimates could also be explained due to our small sample size. Huselid and Becker (1996) argued that a larger sample size is preferable as small ones result in greater variability in observed values across samples. It can also be argued that the financial industry chosen in the present work relatively employs different types of operations (e,g., banks, insurance, real-state etc..) which makes for less consistency in HRM practices and policies, thus driving down reliability estimates (Gerhart et al., 2000). Finally, we would like also to highlight the issue of the level of analysis. This work is conducted at a firm-level of analysis which also could be a reason of having low reliability estimates. It was argued that reliability estimates can be lower at high level of analysis due to the difficulty in precisely measuring HR practices and the fact that these practices may be different across units within the firm (Gerhart et al., 2000).

In addition to the abovementioned tests, Fornell \& Larcker (1981) propose a method to test discriminant validity, claiming that the researcher can establish discriminant validity if the square root of the average variance extracted for a specific construct is greater than the absolute value of the standardised correlation of this specific construct with any other construct. As a result, the square roots of AVE values were compared with the constructs' correlations, with the results showing that the squared roots of the AVE values were higher than any correlation of the HR practices constructs, indicating an acceptable level of discriminant validity (ibid.).

TABLE-1 ABOUT HERE 


\section{Outcome Variables}

Perceived Financial Performance: Following almost all the work that has measured OP subjectively (see, for example, Delaney \& Huselid, 1996; Wright et al., 1999; Fey et al., 2000; Green et al., 2006; Joseph \& Dai, 2009; Razouk, 2011), perceived financial performance was measured by three items in a Likert scale by a special section in the questionnaire, which directly asked respondents in the targeted companies to rate their main financial criteria comparing to their rivals in the industry in the past year (see Wright et al., 2005; Darwish and Singh, 2013). Factor analysis indicated that these items remained strong measures reflecting this variable, namely profitability (after tax), holding market share, and sales revenue. As recorded in Table 1, the items had individual loadings ranging from 0.958 to 0.978 , thus emphasising extremely highly reliable items to measure this variable. Moreover, the test of internal consistency revealed that the overall measures of perceived financial performance highly satisfied the reliability criterion $(\alpha .95)$. Finally, we have also computed the variance inflation factor (VIF) in the regression model of HR practices and perceived financial performance. Lower levels of VIF are more desirable, as higher levels of such test are known to affect adversely the results associated with a multiple regression analysis. As a rule of thumb, a value greater than 10 is a good value at which to worry, and it may merit further investigation (see Kennedy, 1992; Field, 2009; Hair et al., 2010). However, other scholars (see, for example, Rogerson, 2001) recommended a maximum VIF value of 5 and even 4 (see Pan \& Jackson, 2008). In our case, as recorded in Table 5, VIF values were all acceptable ranging from around 2 to 4.

Actual Financial Performance: Return on assets (ROA) and Return on Equity (ROE) are two essential outcome variables considered in the literature as indicators of firm financial performance (see, for example, Keats, 1988; Snell \& Youndt, 1995; Delery \& Doty, 1996; 
Singh et al., 2012). ROA has been used as a measure of efficiency and resource exploitation in organisations (Keats, 1988; Snell \& Youndt, 1995). ROE, in contrast, represents the eventual measure of the strength of any financial organisation (Earle \& Mendelson, 1991). Retaining these variables for our study, data on these was obtained from ASE database. The study also follows the cross-sectional design wherein both predictors and outcome variables are measured on one occasion only. In this regard, HRM-performance cross-sectional research designs can be conducted using one of four main designs (see Wright et el., 2005) which are: Post-predictive designs; Retrospective design; Contemporaneous design; and Predictive design. Published in Personnel Psychology, the work of Wright and his colleagues, inter alia, summarizes the results from 68 empirical studies. Of these $50(72 \%)$ used post-predictive methodology to investigate the HR-performance links (see, for example, Arthur, 1994; MacDuffie, 1995; Delaney and Huselid, 1996; Wright et al. 1999; Bae and Lawler, 2000; Way, 2002; Datta et al., 2005). We followed the post-predictive design in our work as such a design measures HRM practices and policies after the performance period, resulting in actually predicting past performance (Wright et el., 2005). The measures of ROA and ROE for this study were the year-end measures for 2007, and the survey was completed in 2008 . We do not argue that the post-predictive design is the fool-proof method of analyzing the link between HRM and performance. In an extensive survey of literature that precedes and follows this particular quote, Wright et al. (2005a) essentially point out that there are limitations to whatever method the researcher employs to measure HR-performance link which are serious and should be prudently interpreted.

\section{Control Variables}

Firm size and age are commonly used control variables in the studies on HRM-performance link that can cause significant variations in the impact of HRM practices on OP (c.f. Collins \& Clark, 2003). In this study, firm size and firm age are duly employed as control variables, 
measured respectively in natural logs (see also Kimberly, 1976) by the number of employees in each company and the number of years the company has been in operation.

\section{Results}

\section{Descriptive Results}

Table 2 reports the means, standard deviations, skewness and kurtosis of all variables. As stated earlier, the results of the normality test reveal that the variables' skewness and kurtosis values lie within the acceptable limit of ranges, except for firm size and firm age, which were then transformed into logs. Table 3 presents the results of zero-order correlations of all predictors under consideration. It is instructive to note at the very outset that the relationship between HR practices is significant. A certain amount of correlation between the independent variables is expected; in fact, this is considered a good sign. Although some variables are highly correlated, the results show that no multicollinearity is evident (Tabachnick and Fidell, 2007). This would suggest that, whilst different sets of HR practices may be complementary (McDuffie 1995; Ichniowski \& Shaw, 1999; Hall \& Soskice 2001), it is possible that the optimal configuration may not only be contingent upon national context, but also due to the sector and specific characteristics of the firm. Performance appraisal was negatively correlated with all other scales. This may reflect institutional or cultural barriers to general acceptance of performance appraisal in Middle East settings (see Idris, 2007).

\section{TABLE-2 ABOUT HERE}

\section{TABLE 3 ABOUT HERE}

HRM and Objective Measures of Organisational Performance

In this hypothesis, the direct relationship between HR practices and financial performance, as represented by ROA and ROE, is tested. We conducted hierarchical multiple regression as it 
is the most widely employed regression technique in HRM-performance research (Bae \& Lawler, 2000). The results are reported in Table 4, where control variables are entered in the first step and HR practices in the second step. The value of the $\mathrm{R}^{2}$ for ROA model is significant $\left(\mathrm{R}^{2}=.43, F=8.42, p<.001\right)$. In contrast, $\mathrm{R}^{2}$ for $\mathrm{ROE}$ also shows a significant level of explanation of the outcome $\left(\mathrm{R}^{2}=.25, F=3.83, p<.05\right)$ but not as much as the amount explained in the case of ROA.

After controlling for firm size and firm age, the results show that HR practices explain a significant incremental level of variance beyond the controls explained in $\mathrm{ROA}\left(\Delta \mathrm{R}^{2}=.38, F\right.$ for $\left.\Delta \mathrm{R}^{2} 10.06, p<.001\right)$ and in $\mathrm{ROE}\left(\Delta \mathrm{R}^{2}=.25, F\right.$ for $\left.\Delta \mathrm{R}^{2}=4.94, p<.001\right)$. Hence, we can conclude that the regression model results in a significantly better predication of ROA than ROE, as can be seen from the value of $F$ statistics for $\Delta \mathrm{R}^{2}$, which is much higher in the case of ROA. Nonetheless, these results only provide weak support in terms of the number of specified relationships with objective financial performance. Of the six HR practices, training is the only practice positively related to ROA $(b=.52, \mathrm{p}<.01)$, and is marginally positively related to ROE $(b=.34, \mathrm{p}<.10)$. Regarding the rest of the HR practices, the results revealed no significant positive effects on financial performance. Accordingly, the question is posed: why does training have such a strong effect? As Brewster et al. (2012) note, training is an ambiguous measure in that firms may devote more attention to it either owing to a long-term commitment to employees and a high level of mutual interdependence, or otherwise owing to the need for basic induction to compensate for high levels of staff turnover. In short, a devotion to training may not necessarily be an indicator of either soft or instrumental HRM, but a prerequisite for organisational effectiveness should the firm follow either route. In other words, it is a broad policy prescription that may have relevance for very different reasons.

We next assessed the practical significance of the impact of training as the only HR practice affecting financial performance by calculating the consequence of a one-standard-deviation 
increase in training on the numerator of each dependent variable. Results indicated that one SD higher than the average on training is estimated to be 2.93 higher on ROA. As for ROE, in contrast, firms' one SD higher than the average on training is estimated to be 3.12 higher on ROE. Accordingly, considering that these models control for firm size and firm age, the impact of training on financial performance is practically as well as statistically significant.

\section{TABLE 4 ABOUT HERE}

HRM and Subjective Measures of Organisational Performance

This hypothesis is a replication of the first hypothesis with only one difference, which is using the subjective or perceived financial performance instead of the actual one. The results of the hierarchical multiple regressions are shown in Table 5. In the first step, the control variables were entered, namely firm size and firm age, with all HR practices subsequently entered in the second step so as to examine their effects on perceived financial performance.

The value of $\mathrm{R}^{2}$ is highly significant $\left(\mathrm{R}^{2}=.75, F=43.29, p<.001\right)$. With firm size and firm age controlled, the results show that HR practices explain a strong significant incremental level of variance in $\mathrm{R}^{2}$ beyond what the controls explain in perceived financial performance $\left(\Delta \mathrm{R}^{2}=.72, F\right.$ for $\left.\Delta \mathrm{R}^{2} 43.85, p<.001\right)$. Looking at the individual contributions for each practice, once again, training significantly affects perceived financial performance $(b=.30, p$ $<.01)$. However, in addition, internal career opportunities $(b=.20, p<.05)$, as well as extrinsic incentives and rewards $(b=.33, p<.01)$, have significant impacts on perceived financial performance. The latter (and to an extent the former) - in other words, material rewards accruing to rational actors - is perhaps not a surprising result given the dominant agency view within the financial services industry (see Froud et al. 2006; Erturk et al., 2008). With regard to the rest of the HR practices, the results revealed no significant effects of 
recruitment and selection, performance appraisal system, and intrinsic incentives and rewards on perceived financial performance. It can be seen clearly from the results of the regression analysis that $\mathrm{HR}$ practices in the targeted companies can completely and better impact perceived financial performance than the actual financial performance as measured by ROA and ROE. We discuss these results further in the discussion section.

\section{TABLE 5 and 6 ABOUT HERE}

\section{Relationship between Objective and Subjective Performance Measures}

A zero-order correlation between subjective and objective financial performance measures was conducted, as recorded in Table 6 . The results are completely at odds with what has been argued in the literature (c.f. Dess \& Robinson, 1984; Tzafrir 2005). Understandably and expectably, ROA and $\mathrm{ROE}$ - which represent the measures of the actual financial performance-are significantly correlated. However, what cannot be expected is the relationship between the perceived and actual measures of financial performance. As can be noted from Table 6, perceived financial performance is negatively and significantly correlated with objective financial performance.

\section{Discussion and Conclusions}

With regard to our first proposition, of all the HR practices, training was found to be statistically significant in having a strong impact on actual financial performance; in particular on ROA, and a weak effect on ROE. Such results completely contradict other studies that have employed actual measures of financial performance (see, for example, Delery \& Doty, 1996) where researchers have not found any positive associations between training and actual measures of ROA and ROE. In the past, very few studies have employed objective financial indicators, such as ROA and ROE, which makes comparisons difficult. However, broadly speaking — and regardless of the type of performance measures used — the 
results of this are found to be consistent with the findings of a wide range of researchers (see, for example, Delaney \& Huselid, 1996; Wright et al., 2003; Chand \& Katou, 2007; Moideenkutty et al., 2011) on the impact of training, although these studies have established that a range of other HR practices also had a positive impact. Why is training of such universal relevance? As noted above, firms may engage in training in response to diametrically opposed strategies; it may be both a sign of a long-term commitment to people and a response to high staff turnover, necessitating a strong emphasis on induction and orientation (Brewster et al., 2012). Hence, a commitment to training does not, in itself, represent a strong indicator of a specific underlying HR strategy, but may be one that is closely linked to performance. Regardless, however, whatever the underlying rationale, a failure to invest in training of some sort or another is likely to undermine results.

However, our results do not tally with these studies in terms of the impacts of the other HR practices on performance. A probable reason for such differences in terms of not finding or lacking other significant effects for the rest of HR practices on performance is that most previous studies have linked HR practices with subjective indicators rather than objective indicators. Such a conclusion is evidenced in the work, with completely different results seen, even when using the same HR practices and same performance measures. More specifically, internal career opportunities and extrinsic incentives and rewards have significant impacts on perceived financial performance, but not on actual performance. Such findings are in line with the majority of previous works, where researchers have found positive associations between HR practices and perceptual measures of OP (for example, Delaney \& Huselid, 1996; Wright, 2003; Chand \& Katou, 2007; Joseph \& Dai, 2009; Razouki, 2011; Moideenkutty et al., 2011). Why is this the case? Firstly, as noted above, it could reflect the widespread currency of the view that material incentives to staff are likely to optimise 
organisational performance - a viewpoint particularly prevalent in the financial services industry (Froud et al., 2006; Erturk et al., 2008). Secondly, it could reflect the extent to which Western-derived models of best practice may have little relevance in an emerging market setting (c.f. Webster \& Wood, 2005).

Comparing both sets of results, it can be seen that HR practices have a much stronger impact on perceived financial performance than the actual financial performance measured by ROA and ROE. With firm size and firm age controlled, the results show that HR practices explain a strong significant incremental level of variance in $\mathrm{R}^{2}$ beyond what the controls explain in perceived financial performance $\left(\Delta \mathrm{R}^{2}=.72, F\right.$ for $\left.\Delta \mathrm{R}^{2} 43.85, p<.001\right)$, whilst the same practices explain much less significant incremental level of variance beyond what the controls explain in $\mathrm{ROA}\left(\Delta \mathrm{R}^{2}=.38, F\right.$ for $\left.\Delta \mathrm{R}^{2} 10.06, p<.001\right)$ and in $\mathrm{ROE}\left(\Delta \mathrm{R}^{2}=.25, F\right.$ for $\left.\Delta \mathrm{R}^{2}=4.94, p<.001\right)$. Additionally, comparing the individual contributions of HR practices, training was as the only HR practice seen to significantly impact the actual financial performance, although three HR practices (training, internal career opportunities, and extrinsic incentives and rewards) are significantly related to perceived financial performance.

Hence, the second proposition was disproved: findings are inconsistent with previous works that established a positive correlation between actual and perceived financial performance (Dess \& Robinson, 1984; Powell, 1992; Tzafrir, 2005). In addition, our results contradict with what has been argued in the literature that self-reported measures of OP are good enough, can reflect actual performance measures, and enable managers to factor in companies' objectives when evaluating their performance (for example, Dess \& Robinson, 1984; Geringer \& Hebert, 1991; Delaney \& Huselid, 1996; Fey et al., 2000; Richard \& Johnson, 2001; Chang \& Huang, 2005; Green et al., 2006; Andersen et al., 2007; Chand \& Katou, 2007; Joseph \& Dai, 2009; Katou \& Budhwar, 2010; Lee et al., 2010; Moideenkutty et al., 2011; Razouk, 2011). In contrast, such a finding would support that which has been 
argued by some researchers (for example, Lumpkin \& Dess, 1996; Wall \& Wood, 2005), which is that it would be more appropriate and rewarding to use multi-dimensional measures for performance as these measures could include various objective variables to reduce the probability of common method variance, and to thereby avoid misleading normative and descriptive theory-building.

This finding could also reflect the extent to which the dominant prevailing frame of reference within the industry has perhaps served to cloud the judgment of managers. What the results suggest is that managers believe that, employees, as rational profit-maximising individuals, are likely to be primarily motivated by extrinsic rewards (pay and career progression), and that if the firm adopts such measures, the organisation will inevitably perform better. Again, if managers feel they are being judged largely or exclusively on the financial performance of the organisation, they may be reluctant to concede the firm is doing less than optimally as this will amount to an admission of their shortcomings. It is precisely within such firms that a stronger commitment to instrumentalist ways of managing people is likely to be encountered.

This leads to the question concerning why a greater range of HR practices does not impact real organisational performance, in contrast to the wishful thinking of managers. The fact that the main predictor, i.e. training, is an ambiguous measure with a strong commitment to training flowing out of radically different underlying HR strategies would suggest that the efficacy of HR practices is contingent on not only national circumstances but also the specific characteristics of the firm, and indeed its relationship with governments, other firms, and associations (c.f. Lane \& Wood, 2009). It is possible that, as suggested by the literature on comparative capitalism, emerging market institutions are not nearly as closely coupled as their mature market counterparts, making the emergence of coherent, complementary sets of practices less likely (Hall \& Soskice 2001; Hancke et al., 2007). We found little evidence to 
suggest that either coherent hard or soft HR policies are capable of generating superior results in objective terms. Whilst this may be hardly surprising, what was more so as that there was a recognisable alternative HR paradigm more closely aligned to local institutional realities, which appeared capable of generating superior results in the Jordanian setting. This may reflect the extent to which institutions in emerging markets are less closely aligned and coherent, making for fewer complementarities (c.f. Hancke et al., 2007). Does this mean that the bulk of HR practices has little or no effect on organisational performance? The study did not encounter diffuse diversity; rather, it would suggest that very different approaches may be equally valid in developing market settings where institutional supports are weaker and more fluid, as Al-Hasan \& James (2003) suggest may be the case in the Jordanian context. At the same time, the choice of specific HR practices may have consequences on a wide range of other areas than returns to shareholders in the short-term, such as the well-being of employees and other stakeholders, which, in turn, may impact the long-term viability of the firm (Aoki, 2010). The latter may have little relevance for those primarily concerned with short-term results, but are relevant for longer term investors and, indeed, the community at large (Dore, 2000).

Implications for Practice

This study is one conducted in an emerging market in the Middle East. At the same time, the findings have relevance for practice both within the context in which the research was conducted, and more broadly. Whatever their applicability within mature markets, it appears that the usage of specific sets of best practices (be they instrumental or softer) have little impact on organisational performance in Jordan; nor does an optimal configuration of HR practices readily emerge within the Jordanian financial services industry. This would suggest that what works for individual firms may not work for many seemingly comparable organisations. Whilst these may represent an example of extreme contingency, it is worth 
noting that some existing research on the developing world suggests that firms in such contexts often rely on undocumented practices that do not readily coincide with modern approaches to HRM (Webster \& Wood, 2005). Such practices may include the extensive usage of informal family and clan networks in recruitment, and the extent to which formal pay systems may be supplemented by informally extended assistance (ibid; c.f. Aladwan et al., 2011). Local and expatriate managers who ignore such realities may undermine the existing basis of organisational effectiveness without necessarily replacing it with a more viable one. What the existing research on HRM in Jordan alerts us to is that national institutional features realities do not appear to exert a particular strong homogenising impact on firm practice (Al-Hasan \& James, 2003). This would suggest that such informal ties and conventions may induce diversity, rather than a dominant local modus operandi.

Secondly, the study highlights the extent to which managers may have their judgments swayed by dominant dogmas. Within the financial services industry, the assumption that individuals are rational profit-maximising actors, solely motivated by material rewards, has gained particular currency (Froud et al., 2006; Erturk et al., 2008). Even if this is belied by empirical evidence, many respondents appear to have been so swayed by this view so as to hold on to the belief that the extensive usage of material incentives is bound to translate into superior results - even the reality is rather different. This would serve to highlight the extent to which specific HR strategies may be imposed according to senior managerial ideologies, irrespective of whether they work or not, creating considerable challenges for HR professionals.

\section{Limitations}

Despite the contributions of this article, there are nevertheless some limitations to be acknowledged. The study is conducted with regard to one sector (financial) only, and 
although the whole population of firms was very nearly covered, the sample size could have been bigger. Therefore, we suggest that future researchers conduct such a study targeting a larger and more diverse sample. Moreover, data on HRM practices were collected by single respondents from the targeted companies. Time and funds permitting, future researchers can endeavour to use multiple respondents in their work. In addition, the study utilises a crosssectional design. Although we have argued that HRM practices should lead to stronger organisational performance in some cases, our cross-sectional design does not allow us to rule out the possibility of reverse causation (Wright et al., 2005). A longitudinal design would help to strengthen the reverse causation possibility and overcome time-lag effects of HRM on performance (Andersen et a1., 2007). Longitudinal designs on HRM-performance studies are required in order to conclusively and decisively replicate such findings represented here, although such data are costly to obtain and are as yet unavailable in many cases (Huselid, 1995).

Acknowledgments: Authors are indebted to the editor of this journal and two anonymous referees for very constructive comments on an earlier draft of this paper. All shortcomings are ours. Authors would also like to record their debt to Mark Casson and Raymond Loveridge with whom one of the authors earlier worked on an HRM project in Reading. The survey instrument used in this research was partly adopted from this study.

\section{References}

Aladwan, K, Ramudu, B., and Fish, A. (2011). Integrating Western HRM Practices in Jordanian Organisations. Paper presented at Challenges for International Business in a Turbulent Global Environment Conference, Melbourne, 28-30 April.

Alchian, A., and Demsetz, H. (1972). Production, information costs and economic organization. American Economic Review, 62(5), 777-795.

Al-Hasan, S., and James, P. (2003). Cultural control and multinationals: The case of privatized Jordanian companies. International Journal of Human Resource Management, 14(7), 1284-1295.

Al-Shammari, H., and Hussein, R. (2008). Strategic planning in emergent market organizations: An empirical investigation. International Journal of Commerce and Management, 18(1), 47-59.

Altarawneh, I., and Al-Kilani, M. (2010). Human resource management and turnover intentions in the Jordanian hotel sector. Research and Practice in Human Resource Management, 18(1), 46-59.

Amable, B. (2003). The diversity of modern capitalism. Oxford: Oxford University Press. 
Andersen, K., Cooper, B., and Zhu, C. (2007). The effect of SHRM practices on perceived firm financial performance: Some initial evidence from Australia. Asia Pacific Journal of Human Resources, 45(2), 168-179.

Aoki, M. (2010). Corporations in evolving diversity: Cognition, governance and institutions, Oxford: Oxford University Press.

Arthur, J. B. (1994). Effects of human resource systems on manufacturing performance and turnover. Academy of Management Journal, 37(3), 670-687.

Bae, J., and Lawler, J.J. (2000). Organizational and HRM strategies in Korea: Impact on firm performance in an emerging economy. Academy of Management Journal, 43(3), 502-517.

Bahous, V. (2006). The heterogeneity of the financial markets in the Middle East. The Certified Accountant, 1(25). 73-77.

Barney, J.B. (1991). Firm resources and sustained competitive advantage. Journal of Management, 17(1), 99-120.

Barney, J.B. (1995). Looking inside for competitive advantage. Academy of Management Executive, $9(4), 49-61$.

Becker, B. E., and B. Gerhart. (1996). The impact of human resource management on organizational performance: Progress and prospects. Academy of Management Journal, 39(4), 779-801.

Beltran-Martin, I., Roca-Puig, V., Escrig-Tena, A., and Carlos, J., (2008). Human resource flexibility as a mediating variable between high performance work systems and performance. Journal of Management, 34(5), 1009-1045.

Bjorkman, I., and Budhwar, P. (2007). When in Rome? Human resource management and the performance of foreign firms operating in India. Employee Relations, 29(6), 595-610.

Boxall, P., and Purcell, J. (2000). Strategic human resource management: Where have we come from and where should we be going? International Journal of Management Reviews, 2(2), 183-203.

Bratton, J., and Gold, J. (2012). Human resource management: Theory and practice. London: Palgrave.

Brewster, C., Goergen, M., Wood, G. and Wilkinson, A. (2012). Varieties of capitalism and investments in human capital. Industrial Relations, 51(1), 501-527.

Brewster, C., Wood, G. and Brookes, M. (2008). Similarity, isomorphism or duality? Recent survey evidence on the HRM policies of MNCs. British Journal of Management, 19(4) 320-342.

Brewster, C. (2007). The HRM/ performance link: The effects of geography. Developing HR Strategy, 14, 5-9.

Casson, M., Loveridge, R., Singh S. (1996). The Ethical Significance of Corporate Culture in large Multinational Enterprises', in Ethical Universals in Western Business, ed. Brady F.N., Berlin: Springer-Verlag, Studies in Economics, Ethics and Philosophy, 150-172.

Casson, M., Loveridge, R., Singh S. (1997). The Ties that Bond?', in Current Issues in International Business, eds. Islam I, and Shepherd, W, Aldershot, UK: Edward Elgar, 175-206.

Casson, M, Loveridge R., Singh S. (1998). Human Resource Management in Multinational Enterprises: Styles, Modes, Institutions and Ideologies', in Internationalisation: Process, Context and Markets, eds. Hooley G, Loveridge R, Wilson D, Basingstoke UK: Macmillan, 158-170. 
Chand, M., and Katou, A. (2007). The impact of HRM practices on organizational performance in the Indian hotel industry. Employee Relations, 29(6), 576-594.

Chang, W., and Huang, T. (2005). Relationship between strategic human resource management and firm performance: A contingency approach. International Journal of Manpower, 26(5), 434-449.

Central Intelligence Agency. (2009). The World Factbook reports.

Collins C., and Clark, K. (2003). Strategic human resource practices, top management team social networks, and firm performance: The role of human resource practices in creating organizational competitive advantage. Academy of Management Journal, 46(6), 740 - 751.

Crown, W.H. (1998). Statistical models for the social and behavioural sciences: Multiple regression and limited-dependent variable model. Westport CT: Praeger.

Darwish, T. and Singh, S. (2013). Does strategic HR involvement and devolvement enhance organisational performance? Evidence from Jordan. International Journal of Manpower, (forthcoming).

DeCenzo, D., and Robbins, S. (2005). Fundamentals of human resource management. New Jersey: Wiley.

Delaney, J.T. and Huselid, M.A. (1996). The impact of human resource management practices on perceptions of organizational performance. Academy of Management Journal, 39(4), 949-969.

Delery, J. E., and Doty, D. H. (1996). Modes of theorizing in strategic human resource management: Tests of universalistic, contingency and configurational performance predictions. Academy of Management Journal, 39(4), 802-835.

DeShon, R.P (1998). A cautionary note on measurement error corrections in structural equation models. Psychometric Methods. 3,412-423,

Dess, G.G., and Robinson, R.B. (1984). Measuring organizational performance in the absence of objective measures: The case of the privately-held firm and conglomerate business unit. Strategic Management Journal, 5(3), 265 - 279.

Dore R. (2000). Stock market capitalism: Welfare capitalism. Cambridge: Cambridge University Press.

Dore, R. (2008). Best Practice Winning Out? Socio-Economic Review, 6 (4), 779-784.

Dyer, L., and Reeves, T. (1995). Human resource strategies and firm performance: What do we know and where do we need to go? International Journal of Human Resource Management, 6(3), 656-670.

Earle, D.M., and Mendelson, M. (1991). The critical mesh in strategic planning. The Bankers Magazine, 174(3), 48-53.

Erturk, I., Froud, J., Johal, S., Leaver, A. and Williams, K. (2008). Financialization at work: Key texts and commentary. London: Routledge.

Fey, C.F., Bjorkman, I., and Pavlovskaya, A. (2000). The effect of human resource management practices on firm performance in Russia. International Journal of Human Resource Management, $11(1), 1-18$.

Fornell, C., and Larcker, D. (1981). Evaluating structural equation models with unobservable variables and measurement error. Journal of Marketing Research, 18(1), 39-50. 
Froud, H., Johal, S., Leaver, A. and Williams, K. (2006). "Introduction", in Froud, H., Johal, S., Leaver, A. and Williams, K. (eds.), Financialization and strategy: Narrative and numbers. London: Routledge.

Gerhart, B., Wright, P.M. and McMahan, G.C. (2000). Measurement error and estimates of the HR firm performance relationship: Further evidence and analysis. Personnel Psychology, 53, 855-872.

Geringer, M.J., and Hebert, L. (1991). Measuring performance of international joint ventures. Journal of International Business Studies, 28(4), 249-263.

Gooderham, P, Nordhaug, O. and Ringdal, K. (1999). Institutional and rational determinants of organizational practices. Administrative Science Quarterly, 44, 507-531.

Gooderham, P, Nordhaug, O. and Ringdal, K. (2006). National Embeddedness and calculative HRM in US Subsidiaries in Europe and Australia. Human Relations, 59, 1491-1513.

Grant, R.M. (1991). The resource-based theory of competitive advantage: Implications for strategy formulation. California Management Review, 33(3),114-135

Green, K., Wu, C., Whitten, D., and Medlin, B. (2006). The impact of strategic human resource management on firm performance and HR professionals' work attitude and work performance. International Journal of Human Resource Management, 17(4), 559-579.

Guest, D.E. (1997). Human resource management and performance: A review and research agenda. International Journal of Human Resource Management, 8(3), 263-276.

Guest, D.E., (2011). Human resource management and performance: Still searching for some answers. Human Resource Management Journal, 22(1), 3 - 13.

Hair, J.F., Black, W.C., Babin, B.J., and Anderson, R.E. (2010). Multivariate data analysis, New Jersey: Prentice Hall.

Hall, P., and Soskice, D. (2001). "An Introduction to the varieties of capitalism”, Hall, P. and Soskice, D. (eds.), Varieties of capitalism: The institutional basis of competitive advantage, Oxford: Oxford University Press.

Hancke, B., Rhodes, M. and Thatcher, M. (2007). "Introduction", Hancke, B., Rhodes, M. and Thatcher, M. (eds.). Beyond varieties of capitalism: conflict, contradiction, and complementarities in the European economy. Oxford: Oxford University Press.

Hollingworth, M. (2009). "Building 360 organizational sustainability" downloaded from: http://www.iveybusinessjournal.com/topics/global-business/building-360-organizationalsustainability.

Huczynski, A. and Buchanan, D.A. (2007). Organizational Behaviour. London: Financial Times/Prentice Hall.

Huselid, M. (1995). The impact of human resource management practices on turnover, productivity, and corporate financial performance. Academy of Management Journal, 38(3), 635-670.

Huselid, M., and Becker, B. (1996). Methodological issues in cross-sectional and panel estimates of the human resource human resource-firm performance link. Industrial Relations. 353, 400-422.

Ichniowski, C. and Shaw, K. (1999). The effects of human resource management systems on economic performance: An international comparison of U.S. and Japanese plants. Management Science, 45(5), 704-721. 
Idris, A. (2007). Cultural barriers to improving organizational performance in Saudi Arabia. SAM Management Journal, 22/3. Available online at http://www.freepatentsonline.com/article/SAMAdvanced-Management Journal/166537561.html

Jackson, T., Amaeshi, K. \& Yavuz, S. (2008). Untangling African Indigenous Management. Journal of World Business, 43(3), 400-16.

Jensen, M. (2000). "The modern industrial revolution, exit, and the failure of internal control systems", Jensen, M. (ed.), Theory of the firm. Boston: Harvard University Press.

Joseph, K.E. and Dai, C. (2009). HRM practices and organizational performance: An empirical analysis. International Journal of Business and Management, 4(8), 117-127.

Katou, A.A., and Budhwar, P.S. (2010). Causal relationship between HRM policies and organisational performance: Evidence from the Greek manufacturing sector. European Management Journal, 28(1), 25-39.

Katou, A.A., and Budhwar, P.S. (2007). Human resource management systems and organizational performance: A test of a mediating model in the Greek manufacturing context. The International Journal of Human Resource Management, 17(7), 1223-1253.

Keats, B.W. (1988). The vertical construct validity of business economic performance measures. Journal of Applied Behavioural Science, 24(2), 151-160.

Kennedy, P. (1992). A Guide to Econometrics. Oxford: Blackwell.

Kerr, J.L., and Slocum, J.W. (1987). Linking reward systems and corporate cultures. Academy of Management Executive, 1(2), 99-108.

Khandekar, A., and Sharma, A. (2005). Organizational learning in Indian organizations: A strategic HRM perspective. Journal of Small Business and Enterprise Development, 12(2), 211-226.

Kimberly, J. (1976). Organisational size and the structuralist perspective. Administrative Science Quarterly, 21(4), 571-597.

Lane, C. and Wood, G. (2009). Diversity in Capitalism and Capitalist Diversity. Economy and Society, 38(4), 531-551.

Lee, F., Lee, T., and Wu., W. (2010). The relationship between human resource management practices, business strategy and firm performance: Evidence from steel industry in Taiwan. The International Journal of Human Resource Management, 21(9), 1351 - 1372.

Lincoln, J. and Kalleberg, A. (1990). Culture, control and commitment: A study of work organization in the United States and Japan. Cambridge: Cambridge University Press.

Lumpkin, G.T., and Dess, G.G. (1996). Clarifying the entrepreneurial orientation construct and linking it to performance. Academy of Management Review, 21(1), 135-172.

MacDuffie, J. P. (1995). Human resource bundles on manufacturing performance: Organizational logic and flexible production systems in the world auto industry. Industrial and Labour Relations Review, 48(2), 197-221.

Macky, K., and Boxall, P. (2007). The relationship between 'high-performance work practices' and employee attitudes: An investigation of additive and interaction effects. The International Journal of Human Resource Management, 18(4), 537 -567. 
Miles, R. E., and Snow, C. C. (1984). Designing strategic human resources systems. Organizational Dynamics, 13(1), 36-52.

Moideenkutty, U., Al-Lamki, A., and Murthy, Y. (2011). HRM practices and organisational performance in Oman. Personnel Review, 40(2), 239- 251.

Noe, J., Hollenbeck, B., Gerhart and P. Wright. (2006). Human resources management: Gaining a competitive advantage. New York: McGraw-Hill.

Osterman, P. (1987). How common is workplace transformation and who adopts it? Industrial and Labour Relations Review, 47(2), 173-188.

Paauwe, J. (2009). HRM and performance: Achievements, methodological, issues and prospects. Journal of Management Studies, 46(1), 129 -142.

Paauwe, J., and Boselie, P. (2005). HRM and performance: What next? Human Resource Management Journal, 15(4), 68-83.

Pan, Y, and Jackson, R. T. (2008). Ethnic difference in the relationship between acute inflammation and serum ferritin in US adult males. Epidemiology and Infection. 136, 421-431.

Pfeffer, J. (1994). Competitive advantage through people. Boston: Harvard Business School Press.

Pfeffer, J. (1998). Seven practices of successful organizations. California Management Review, 40(2), 96-124.

Powell, T.C (1992). Organisational alignment as a competitive advantage. Strategic Management Journal, 13(7), 119-134.

Razouk, A. (2011). High performance work systems and performance of French small- and mediumsized enterprises: Examining causal order. The International Journal of Human Resource Management, 22(2), 311-330.

Richard, O.C., and Johnson, N.B. (2001). Strategic human resource management effectiveness and firm performance. International Journal of Human Resource Management, 12(2), 299-310.

Rogers, E., and Wright, P. (1998). Measuring organisational performance in strategic human resource management: Problems, prospects, and performance information markets. Human Resource Management Review, 8(3), 311-331.

Rogerson, P. A. (2001). Statistical methods for geography. London: Sage.

Rowe, W. G., Morrow, J. L., and Finch, J. F. (1995). Accounting, market, and subjective measures of firm performance: Three sides of the same coin? Paper presented at the Academy of Management Annual Conference, Vancouver.

Schmidt, F. (1996). Statistical significance testing and cumulative knowledge in psychology: Implications for the training of researchers. Psychological Methods, 1(2), 115- 129.

Schuler, R.S., and Jackson, S.E. (1999). Strategic human resource management, London: Blackwell.

Schuler, R.S. and Jackson, S. E. (1987). Linking competitive strategies with human resource management practices. The Academy of Management Executive, 1(3), 207-219.

Scott, W. R. (1977). Effectiveness of organizational effectiveness studies: New perspectives on organizational effectiveness. San Francisco: Jossey-Bass Publishers. 
Singh, S., Darwish, T., Cristina Costa, A. and Anderson, N. (2012). Measuring HRM and organisational performance: Concepts, issues, and framework. Management Decision, 50 (4), 651-667

Snell, S., and Youndt, M. (1995). Human resource management and firm performance: Testing a contingency model of executive controls. Journal of Management, 21(4), 711-737.

Sonnenfeld, J. A., and Peiperl, M. A. (1988). Staffing policy as a strategic response: A typology of career systems. Academy of Management Review, 13(4), 588-600.

Storey, J. (2007). Human resource management: A critical text. New York: Routledge

Sureshchandar, G., Rajendran, C., Anantharaman, R. and Kamalanabhan, T. (2002). Management's perception of total quality service in the banking sector of a developing economy - a critical analysis. International Journal of Bank Marketing, 20 (4), 181 - 196.

Tabachnick, B. and Fidell, L. (2007). Using multivariate statistics. Toronto: Allyn and Brown.

Tzafrir, S. (2005). The relationship between trust, HRM, and firm performances. International Journal of Human Resource Management, 16(9), 1600-1622.

Venkatraman, N., and V. Ramanujam. (1986). Measurement of business performance in strategy research: A comparison of approaches. Academy of Management Review, 2(2), 801-814.

Wall, T.D., Michie, J., Patterson, M., Wood, S., Sheehan, M., Clegg, C.W. and West, M. (2004). On the validity of subjective measures of company performance. Personnel Psychology, 57, 95-118.

Wall, T.D., and Wood, S. (2005). The romance of human resource management and business performance, and the case for big science. Human Relations, 58(4), 429-462.

Way, S. (2002). High performance work systems and intermediate indicators of firm performance within the US small business sector. Journal of Management, 28(6), 765-785.

Webster, E. and Wood, G. (2005). Human resource management practice and institutional constraints. Employee Relations, 27(4), 369-385.

Wernerfelt, B. (1984). A resource-based view of the firm. Strategic Management Journal, 5(2), 17180 .

Wood, G., Croucher, R., Brewster, C., Brookes, M. and Collings, D. (2009). Varieties of firm: Complementarity and bounded diversity. Journal of Economic Issues, 43(1), 239-258.

Wood, S., and de Menezes, L. (2008). Comparing perspectives on high involvement management and organizational performance across the British economy. The International Journal of Human Resource Management, 19(4), 639-683.

Wright, P.M., and Gardner, T.M. (2003). The human resource-firm performance relationship: Methodological and theoretical challenges. In the new workplace: A guide to the human impact of modern working practices, (eds), D. Holman, T.D. Wall, C.W. Clegg, P. Sparrow, and A. Howard, pp. 311-28. West Sussex, UK: Wiley.

Wright, P.M., and McMahan, G.C. (1992). Theoretical perspectives for strategic human resource management. Journal of Management, 18(2), 295-321

Wright, P.M., Gardner, T.M., and Moynihan, L.M. (2003). The impact of HR practices on the performance on business units. Human Resource Management Journal, 13(3), 21-36.

Wright, P.M., Gardner, T.M., Moynihan, L.M. and Allen, M.R. (2005). The relationship between HR practices and firm performance: Examining causal order. Personnel Psychology, 58, 409-446. 
Wright, P., Gardner, T., Moynihan, L.M, Park, H., Gerhart, B. and Delery, J. (2001). Measurement error in research on human resources and firm performance: Additional data and suggestions for future research. Personnel Psychology. 54, 875-902.

Wright, P.M., McCormick, B., Sherman, W.S., and McMahan, G.C. (1999). The role of human resource practices in petro-chemical refinery performance. International Journal of Human Resource Management, 10(4), 551-571.

Table 1: Convergent validity (standardized factor loadings, average variance extracted, and reliability results)

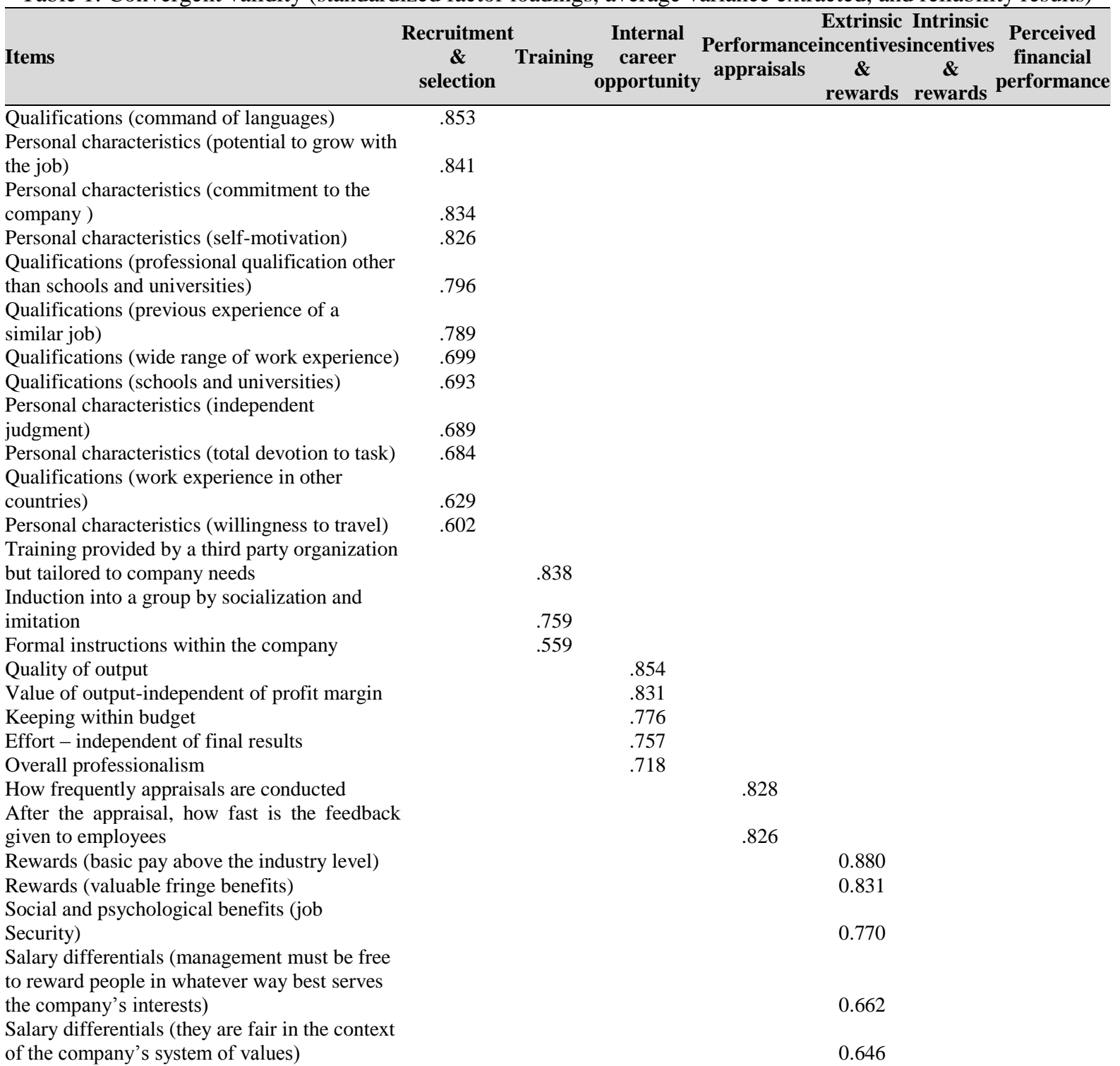


Salary differentials (they reflect the firm's own evaluation of the jobs people perform)

Rewards (better career prospects than other

firms in the same industry)

Social and psychological benefits (the prestige

of working for one of the top firms in the

industry)

Rewards (the opportunity to earn large bonuses through greater efforts)

Social and psychological benefits (friendly and

supportive colleagues)

inflation rate)

and challenging work)

Profitability (after tax)

Sales revenue

Holding market share

Average Variance Execrated (AVE)

Reliability (cronbach's alpha)

.56
.93

$\begin{array}{lll}.93 & .63 & .83\end{array}$

Note: All deleted items (not reported in this table) had factor loadings below .55, which is considered the minimum significance level in comparison with our sample size (Hair et al., 2010) 
Table 2: Basic statistics on variables

\begin{tabular}{lcccccccc}
\hline \multirow{2}{*}{ Variables } & \multicolumn{2}{c}{ Mean } & & Variance & \multicolumn{2}{c}{ Skewness } & \multicolumn{2}{c}{ Kurtosis } \\
\cline { 2 - 3 } \cline { 6 - 8 } & Statistic & Std. Error & Std. Deviation & & Statistic & Std. Error & Statistic & Std. Error \\
\hline Recruitment and Selection & 41.14 & .954 & 9.497 & 90.184 & -.100 & .243 & -.899 & .481 \\
Training & 13.25 & .334 & 3.32 & 11.02 & -.045 & .243 & -1.41 & .481 \\
Internal Career & & & & & & & & \\
opportunities & 23.19 & .445 & 4.43 & 19.62 & -.271 & .243 & -.75 & .481 \\
Performance appraisals & 6.18 & .138 & 1.37 & 1.88 & .075 & .243 & -.21 & .481 \\
Extrinsic Incentives and & & & & & & & & \\
Rewards & 27.95 & .56 & 5.58 & 31.16 & -1.00 & .243 & -1.06 & .481 \\
Intrinsic Incentives and & & & & & & & & \\
Rewards & 14.03 & .29 & 2.93 & 8.60 & -.09 & .243 & .035 & .481 \\
ROA & 4.023 & .572 & 5.694 & 32.423 & -.042 & .243 & .093 &. .481 \\
ROE & 7.549 & .933 & 9.291 & 86.337 & -.408 & .243 & .907 & .481 \\
Perceived Financial & & & & & & & & .481 \\
Performance & 17.92 & .875 & 8.70 & 75.76 & .087 & .243 & -1.23 & .481 \\
Firm Size & 3.39 & .195 & 1.94 & 3.78 & 097 & .243 & -.383 & .481 \\
Firm Age & 2.55 & .095 & .952 & .907 & -.355 & .243 & -1.089 & .481 \\
\hline
\end{tabular}

Table 3: Zero-order correlations of variables

\begin{tabular}{|c|c|c|c|c|c|c|c|c|}
\hline Variables & 1 & 2 & 3 & 4 & 5 & 6 & 7 & 8 \\
\hline 1.Recruitment and Selection & 1 & & & & & & & \\
\hline 2. Training & $.73 * *$ & 1 & & & & & & \\
\hline 3.Internal Career Opportunity & $.67 * *$ & $.68 * *$ & 1 & & & & & \\
\hline 4.Performance Appraisals & $-.54 * *$ & $-.52 * *$ & $-.53 * *$ & 1 & & & & \\
\hline 5. Extrinsic Incentives and Rewards & $.63 * *$ & $.65 * *$ & $.68 * *$ & $-.60 * *$ & 1 & & & \\
\hline 6. Intrinsic Incentives and Reward & $.32 * *$ & $.28 * *$ & $.32 * *$ & -.15 & .02 & 1 & & \\
\hline 7. Log Firm Size & $.34 * *$ & $.20^{*}$ & $.27 * *$ & -.16 & $.30^{* *}$ & .09 & 1 & \\
\hline 8. Log Firm Age & $.27 * *$ & .15 & .17 & $-.32 * *$ & $.27 * *$ & -.09 & $.67 * *$ & 1 \\
\hline
\end{tabular}

** Correlation is significant at the 0.01 level (2-tailed). 
Table 4: Hierarchical regression analysis for ROA and ROE

\begin{tabular}{|c|c|c|c|c|c|c|c|c|}
\hline \multirow[t]{2}{*}{ Variables } & \multicolumn{2}{|l|}{ Step 1} & \multicolumn{2}{|l|}{ Step 2} & \multicolumn{2}{|l|}{ Step1 } & \multicolumn{2}{|l|}{ Step 2} \\
\hline & \multicolumn{2}{|l|}{ ROA } & \multicolumn{2}{|c|}{ ROA } & \multicolumn{2}{|l|}{ ROE } & \multicolumn{2}{|c|}{ ROE } \\
\hline & $B$ & Sig. & $B$ & Sig. & $B$ & Sig. & $B$ & Sig. \\
\hline \multicolumn{9}{|l|}{ Controls: } \\
\hline$\overline{\text { Log. Firms Size }}$ & -.215 & .112 & -.341 & $.003^{* *}$ & .038 & .782 & -.050 & .701 \\
\hline Log. Firm Age & .005 & .970 & -.087 & .457 & .59 & .666 & -.023 & .861 \\
\hline \multicolumn{9}{|l|}{ HR Practices } \\
\hline$\overline{\text { Recruitment and Selection }}$ & & & -.164 & .225 & & & -.197 & .202 \\
\hline Training & & & .515 & $.001 * *$ & & & .336 & $.050 \dagger$ \\
\hline Internal Career Opportunities & & & -.040 & .795 & & & .045 & .797 \\
\hline Performance Appraisals & & & -.162 & .221 & & & -.159 & .292 \\
\hline Extrinsic Incentives and Rewards & & & .190 & .227 & & & .189 & .294 \\
\hline Intrinsic Incentives and Rewards & & & .019 & .849 & & & -.015 & .898 \\
\hline $\mathrm{R}^{2}$ & \multirow{3}{*}{\multicolumn{2}{|c|}{$\begin{array}{c}.05(.03) \\
.05\end{array}$}} & \multirow{3}{*}{\multicolumn{2}{|c|}{$\begin{array}{c}.43(.38) \\
.38 \\
10.06^{* * *}\end{array}$}} & \multirow{3}{*}{\multicolumn{2}{|c|}{$\begin{array}{c}.008(-.013) \\
.008\end{array}$}} & \multirow{3}{*}{\multicolumn{2}{|c|}{$\begin{array}{c}.254(.19) \\
.25 \\
4.94 * * *\end{array}$}} \\
\hline$\Delta \mathrm{R}^{2}$ & & & & & & & & \\
\hline $\mathrm{F}$ for $\Delta \mathrm{R}^{2}$ & & & & & & & & \\
\hline Durbin-Watson $^{2}$ & \multicolumn{4}{|l|}{2.18} & \multicolumn{4}{|l|}{2.11} \\
\hline
\end{tabular}

Notes: $\quad \mathrm{N}=99$. Standardized regression coefficients are shown. Adjusted $\mathrm{R}^{2}$ is in parentheses $\dagger p<.10, * p<.05, * * p<$ $.01, * * * p<.001$.

Table 5: Hierarchical regression analysis for perceived financial performance

\begin{tabular}{|c|c|c|c|c|c|}
\hline \multirow[t]{2}{*}{ Variables } & \multicolumn{2}{|c|}{ Step 1} & \multicolumn{3}{|c|}{ Step 2} \\
\hline & $B$ & Sig. & $B$ & Sig. & VIF \\
\hline \multicolumn{6}{|l|}{ Controls: } \\
\hline Log. Firms Size & -.125 & .358 & .139 & $.066 \dagger$ & \\
\hline Log. Firm Age & -.066 & .627 & -.012 & .875 & \\
\hline \multicolumn{6}{|l|}{ HR Practices } \\
\hline$\overline{\text { Recruitment }}$ and Selection & & & .134 & .134 & 2.83 \\
\hline Training & & & .301 & $.003 * *$ & 3.46 \\
\hline Internal Career Opportunities & & & .204 & $.047 *$ & 3.73 \\
\hline Performance Appraisals & & & .026 & .764 & 2.72 \\
\hline Extrinsic Incentives and Rewards & & & .326 & $.002 * *$ & 3.85 \\
\hline Intrinsic Incentives and Rewards & & & .059 & .363 & 1.53 \\
\hline $\mathrm{R}^{2}$ & \multicolumn{2}{|c|}{$.031(.011)$} & \multicolumn{3}{|c|}{$.753(.731)$} \\
\hline$\Delta \mathrm{R}^{2}$ & \multicolumn{2}{|c|}{.031} & \multicolumn{3}{|c|}{.72} \\
\hline $\mathrm{F}$ for $\Delta \mathrm{R}^{2}$ & \multicolumn{2}{|c|}{1.526} & \multicolumn{3}{|c|}{$43.853 * * *$} \\
\hline Durbin-Watson & 1.82 & & & & \\
\hline
\end{tabular}

Notes: $\mathrm{N}=99$. Standardized regression coefficients are shown. Adjusted $\mathrm{R}^{2}$ is in parentheses $\dagger p<.10,{ }^{*} p<$ $.05, * * p<.01, * * * p<.001$.

\footnotetext{
${ }^{2}$ The Durbin-Watson test is largely used in time-series data. However, the statistic of the test can be an important diagnostic indicator even when the researcher is not utilizing time-series data. A statistically significant Durbin-Watson test when the researcher is testing a model based on cross-sectional data can be an indication of specification error such as omitted variables or incorrect functional form (Crown, 1998).
} 
Human Resource Management

Table 6: Zero-order correlations of subjective and objective financial measures

\begin{tabular}{lccc}
\hline Variables & ROA & ROE & $\begin{array}{c}\text { Perceived Financial } \\
\text { Performance }\end{array}$ \\
\hline ROA & 1 & & \\
ROE & $.761^{* *}$ & 1 & 1 \\
Perceived Financial Performance & $-.588^{* *}$ & $-.463^{* *}$ & \\
\hline$* *$ Correlation is significant at the 0.01 level (2-tailed). & &
\end{tabular}

****** 